DOI: http://doi.org/10.21698/simi.2018.fp44

\title{
DETERMINATION OF RHODIUM FROM WASTEWATER SAMPLES USING ICP-EOS TECHNIQUE
}

\author{
Anda Tenea ${ }^{1}$, Cristina Dinu ${ }^{1,2 *}$, Eleonora-Mihaela Ungureanu ${ }^{2}$, Gabriela-Geanina Vasile ${ }^{1}$, \\ Marius Simion ${ }^{1}$ \\ ${ }^{1}$ National Research and Development Institute for Industrial Ecology-ECOIND, 71-73 Drumul \\ Podu Dambovitei, district 6, 060652, Bucharest, *cristinadinu_2006@yahoo.com, Romania \\ ${ }^{2}$ University Politehnica of Bucharest, Faculty of Applied Chemistry and Materials Science, 1-7 \\ Polizu Street, 011061, Bucharest, Romania
}

\begin{abstract}
A rapid, sensitive and accuracy method was developed for detection of rhodium in wastewater samples. The recovery test indicate that $343.489 \mathrm{~nm}$ is the proper wavelenghts for Rh determination.
\end{abstract}

Keywords: ICP-OES, rhodium, water

\section{Introduction}

Rhodium is part of Platinum group elements together with iridium (Ir), osmium (Os), palladium (Pd), platinum (Pt) and ruthenium (Ru). Over the last decade, the platinum metal concentration of environmental samples such as soil, surface water, sediment and vegetation has increased significantly, the main source of contamination with these platinum metals being catalytic converters. Platinum group elements are used in catalysts which reduce pollutants in the exhaust system. Catalysts containing platinum metals are applied especially to motor vehicles but can also be used in industry as stationary catalyst used for oxidation of ammonia. The main sources of platinum metals emissions in Europe: $50.4 \%$ come from catalysts, $24.7 \%$ of jewelry, $6 \%$ from electrical industry, $4.8 \%$ from chemical industry, $4.6 \%$ from glass industry, $2.6 \%$ from oil industry and $6.8 \%$ from other sources (Pawlak 2014).

Large platinum concentration have been found near mines, especially those that extract nickel ores (Dinu 2017). Concentration of platinum metals were found also in different types of water (river, rainwater, groundwater, surface water) (Ravindra 2004, Kim 2017). Due to the use of catalysts, harmful gases (CO, HC, NOx) emitted by cars are oxidized and reduced to harmless gases (CO2, H2O, N2) (Yajun 2012). In high concentration platinum metals give mutagenic effects in bacterial and mammalian cells and tumor growth. The platinum metal concentration in the environment are low and their health effects are poorly studied (Merget 2001).

Rhodium is present at about $0.001 \mathrm{mg} / \mathrm{L}$ in the earth's crust. Rhodium is a whitesilver metal with a higher melting point and a lower density than platinum. Platinum elements usually do not form oxides and are not affected by the most acids. It is completely insoluble in nitric acid, poorly soluble in aqua regia, but only sulfuric acid can dissolve completely when it is in the form of a powder. Being a noble metal, pure rhodium is chemically inert, but becomes very reactive in chemical 


\section{INTERNATIONAL SYMPOSIUM "THE ENVIRONMENT AND THE INDUSTRY", SIMI 2018, PROCEEDINGS BOOK}

combinations. Rhodium is used in combination with platinum for thermocouples, crucibles, evaporating dishes, etc. (Panahi 2009).

Rhodium found in nature consists of one isotope, ${ }^{103} \mathrm{Rh}$ of the thirty-eight discovered so far (Parker 2012).

The most commonly used analytical techniques for rhodium determination are: graphite furnace atomic absorption spectrometry (GFAAS) (Su 2001, Zimmermann 2003), instrumental neutron activation analysis (INAA) (Dai 2001), adsorptive stripping voltammetry (ASV) (Georgieva 1997), inductively coupled plasma-atomic emission spectrometry (ICP-AES) (Kovacheva 2002) and inductively coupled plasma-mass spectrometry (ICP-MS) (Petrucci 2000, Niemela 2004, Djingova 2003, Gomez 2000, Resano 2007, Muzikar 2006).

The aim of this study was to develop a method for the determination of rhodium from wastewater samples using ICP-OES technique.

\section{Materials and Methods}

Reagents : Standard solution for Rhodium calibration, $10 \mathrm{mg} / \mathrm{L}$ ICP-MS Standard, Sigma - Aldrich quality; nitric acid for trace analysis $\geq 69 \%$, Fluka; ultrapure water; argon 99,996\% purity; nitrogen 99,999\% purity (Linde-Gas quality).

Equipment: Inductively Coupled Plasma Optical Emission Spectrometer ICP-OES Type Optima 5300 DV Perkin Elmer.

Optimized instrumental parameters are summarized in Table 1.

Table 1. Parameters for ICP-EOS

Spectrometer parameters

\begin{tabular}{|c|c|c|c|}
\hline \multicolumn{2}{|c|}{ Rh Wavelengths: $233.477 \mathrm{~nm} ; 343.489 \mathrm{~nm}$} & Replicates & 3 times \\
\hline \multicolumn{2}{|l|}{ Integration time: $0.05 \mathrm{~s}$} & Purge Gas Flow & normal \\
\hline \multicolumn{2}{|c|}{ Transient Read Time $30.0 \mathrm{~s}$} & \multicolumn{2}{|c|}{ Transient Read Delay $0.0 \mathrm{~s}$} \\
\hline \multicolumn{4}{|c|}{ Plasma parameters } \\
\hline Plasma flow rate & $15 \mathrm{~L} / \mathrm{min}$ & Power RF & 1400 \\
\hline Auxiliary flow rate & $0.2 \mathrm{~L} / \mathrm{min}$ & Plasma View & Axial \\
\hline Nebulizer flow rate & $0.7 \mathrm{~L} / \mathrm{min}$ & View distance & $15.0 \mathrm{~mm}$ \\
\hline
\end{tabular}

\section{Method verification}

In order to validate the developed method under the established optimized condition were investigate the performance parameters: limits of detection (LOD), limits of quantification (LOQ), linearity, accuracy (precision, recovery). The tests performed are indicated in Table 2.

Table 2. Experimental design for method verification

\begin{tabular}{ll}
\hline Linearity test & 5 solutions in the range $0.1 \mathrm{mg} / \mathrm{L}$ to $0.5 \mathrm{mg} / \mathrm{L} \mathrm{Rh}$ \\
\hline LOD, LOQ & 5 independent fortified blank solution of $0.04 \mathrm{mg} / \mathrm{L} \mathrm{Rh}$ \\
\hline Repeatability & 10 independent standard solution of $0.3 \mathrm{mg} / \mathrm{L} \mathrm{Rh}$ \\
\hline Intermediate & $\begin{array}{l}4 \text { independent standard solution analyzed by } 2 \text { chemists in } 2 \text { different } \\
\text { precision }\end{array}$ \\
\hline Recovery & $\begin{array}{l}\text { days, } 16 \text { independent standard solution of } 0.3 \mathrm{mg} / \mathrm{L} \mathrm{Rh} \\
\end{array}$ \\
& samples with $0.04 \mathrm{mg} / \mathrm{L} \mathrm{Rh}$ \\
\hline
\end{tabular}




\section{INTERNATIONAL SYMPOSIUM "THE ENVIRONMENT AND THE INDUSTRY", SIMI 2018, PROCEEDINGS BOOK}

The mathematical equation for relative standard deviation (coeficient of variation) and recovery are:

Recovery, \%

$$
\eta=\frac{X_{f-} X_{b}}{X_{a}} * 100
$$

where $\mathrm{X}_{\mathrm{f}}$ is mean value of fortified samples, $\mathrm{mg} / \mathrm{L}$; $\mathrm{X}_{\mathrm{b}}$ is mean value of unfortified samples, $\mathrm{mg} / \mathrm{L} ; \mathrm{X}_{\mathrm{a}}$ is concentration of added standard solution, $\mathrm{mg} / \mathrm{L}$.

Relative standard deviation, $R S D$

$$
R S D=\frac{S_{r}}{x} * 100
$$

where $\mathrm{S}_{\mathrm{r}}$ is standard deviation of concentrations, $\mathrm{mg} / \mathrm{L} ; \mathrm{x}$ is mean value of concentrations, $\mathrm{mg} / \mathrm{L}$.

\section{Results and Discussion}

The calibration standards were prepared in the range 0.1 to $0.5 \mathrm{mg} / \mathrm{L} \mathrm{Rh}$ in $3 \%$ nitric acid for trace analysis using a $10 \mathrm{mg} / \mathrm{L}$ Rh Certified Reference Material. The calibration curve and all tested parameters was performed at two different wavelengths: $233.477 \mathrm{~nm}$, respectively $343.489 \mathrm{~nm}$. In Figures 1 and 2 are plotted the calibration curve, the determination coefficients were higher than the minimum accepted value (0.995).

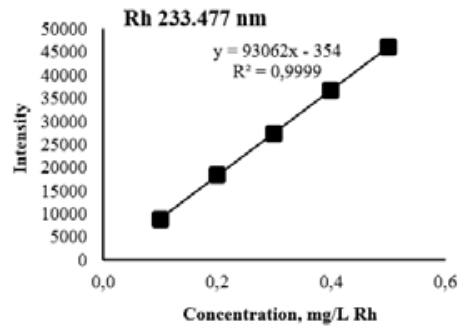

Figure 1. Calibration curve, $233.477 \mathrm{~nm}$

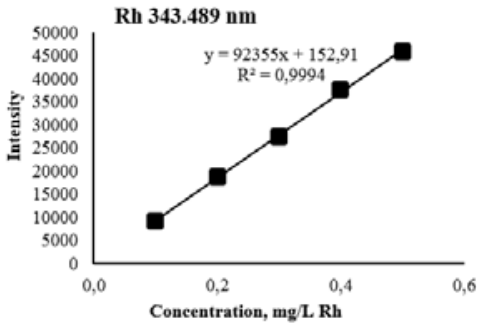

Figure 2. Calibration curve, $343.489 \mathrm{~nm}$

The working range is linear between $0.1 \mathrm{mg} / \mathrm{L}$ and $0.5 \mathrm{mg} / \mathrm{L}$ for both wavelengths $(233.477 \mathrm{~nm}$ and $343.489 \mathrm{~nm})$ and the value for coefficient of variation $(0.36 \%$ for $233.477 \mathrm{~nm}$ and $0.92 \%$ for $343.489 \mathrm{~nm}$ ), less then $2 \%$ according to Horwitz function (Hibbert 2007), situate the test method as good spectrometric method (Table 3). 


\section{INTERNATIONAL SYMPOSIUM "THE ENVIRONMENT AND THE INDUSTRY", SIMI 2018, PROCEEDINGS BOOK}

Table 3. Linearity test coefficients

\begin{tabular}{|c|c|c|}
\hline \multicolumn{3}{|c|}{ Rh, $233.477 \mathrm{~nm}$} \\
\hline & $y=93062 x-354$ & \\
\hline $\begin{array}{c}\mathrm{y} \text {-Intercept } \\
\mathrm{a}=-354 \mathrm{mg} / \mathrm{L}\end{array}$ & $\begin{array}{l}\text { Sensitivity = slope of the } \\
\text { calibration curve } \\
\text { b }=93062 \mathrm{mg} / \mathrm{L}\end{array}$ & $\begin{array}{c}\text { Correlation coefficient } \\
\mathrm{R}=0,99995\end{array}$ \\
\hline $\begin{array}{c}\text { Residual standard } \\
\text { deviation } \\
\mathrm{S}_{\mathrm{Y}}=101.1 \mathrm{mg} / \mathrm{L}\end{array}$ & $\begin{array}{c}\text { Standard deviation of the } \\
\text { method } \\
\mathrm{S}_{\mathrm{x}}=0.0011 \mathrm{mg} / \mathrm{L}\end{array}$ & $\begin{array}{c}\text { Coefficient of variation of the } \\
\text { method } \\
V_{\mathrm{x} 01}=0.36 \%\end{array}$ \\
\hline \multicolumn{3}{|c|}{ Rh, $343.489 \mathrm{~nm}$} \\
\hline & $y=92355 x+152.91$ & \\
\hline $\begin{array}{c}\mathrm{y} \text {-Intercept } \\
\mathrm{a}=152.91 \mathrm{mg} / \mathrm{L}\end{array}$ & $\begin{array}{c}\text { Sensitivity = slope of the } \\
\text { calibration curve } \\
\text { b }=92355 \mathrm{mg} / \mathrm{L}\end{array}$ & $\begin{array}{c}\text { Correlation coefficient } \\
\mathrm{R}=0,9994\end{array}$ \\
\hline $\begin{array}{c}\text { Residual standard } \\
\text { deviation } \\
\mathrm{S}_{\mathrm{Y}}=255 \mathrm{mg} / \mathrm{L}\end{array}$ & $\begin{array}{c}\text { Standard deviation of the } \\
\text { method } \\
\mathrm{S}_{\mathrm{x}}=0.0028 \mathrm{mg} / \mathrm{L}\end{array}$ & $\begin{array}{c}\text { Coefficient of variation of the } \\
\text { method } \\
\mathrm{V}_{\mathrm{x} 01}=0.92 \%\end{array}$ \\
\hline
\end{tabular}

Five independent blank samples (ultrapure water) were fortified with $0.04 \mathrm{mg} / \mathrm{L} \mathrm{Rh}$ in order to quantify the detection limit (LOD) and the quantification limit (LOQ). The results obtained are presented in Table 4.

Table 4. Parameters in experiments for LOD and LOQ

\begin{tabular}{|c|c|c|c|c|c|}
\hline \multicolumn{6}{|c|}{$\mathrm{Rh}, 233.477 \mathrm{~nm}$} \\
\hline $\begin{array}{c}\text { Measured values } \\
(\mathrm{mg} / \mathrm{L})\end{array}$ & 0.047 & 0.047 & 0.043 & 0.043 & 0.034 \\
\hline \multicolumn{6}{|c|}{$\begin{array}{l}\text { Standard deviation of the results, } \mathrm{s}=0.005 \mathrm{mg} / \mathrm{L} \\
\text { Limit of detection, } \mathrm{LOD}=3 \mathrm{~s}=0.016 \mathrm{mg} / \mathrm{L} \\
\text { Limit of quantification, } \mathrm{LOQ}=10 \mathrm{~s}=0.05 \mathrm{mg} / \mathrm{L}\end{array}$} \\
\hline \multicolumn{6}{|c|}{$\mathrm{Rh}, 343.489 \mathrm{~nm}$} \\
\hline $\begin{array}{c}\text { Measured values } \\
(\mathrm{mg} / \mathrm{L})\end{array}$ & 0.031 & 0.037 & 0.035 & 0.036 & 0.038 \\
\hline
\end{tabular}

Standard deviation of the results, $\mathrm{s}=0.003 \mathrm{mg} / \mathrm{L}$

Limit of detection, $\mathrm{LOD}=3 \mathrm{~s}=0.01 \mathrm{mg} / \mathrm{L}$

Limit of quantification, $\mathrm{LOQ}=10 \mathrm{~s}=0.03 \mathrm{mg} / \mathrm{L}$

For precision in terms of repeatability of the method, ten samples of $0.3 \mathrm{mg} / \mathrm{L} \mathrm{Rh}$, prepared from $10 \mathrm{mg} / \mathrm{kg}$ Rh (III) in nitrate solution were analyzed. The precision test was performed by one analyst with the same equipment and method, in one day. In Table 5 are presented the experimental data for precision test.

Table 5. Experiments for repeatability

\begin{tabular}{cccccc}
\hline & \multicolumn{7}{c}{ Rh, 233.477 nm } \\
\hline $\begin{array}{c}\text { Measured values } \\
(\mathrm{mg} / \mathrm{L})\end{array}$ & 0.298 & 0.301 & 0.300 & 0.299 & 0.298 \\
\cline { 2 - 6 } & 0.306 & 0.299 & 0.298 & 0.302 & 0.308 \\
\hline
\end{tabular}

Standard deviation of the results, $\mathrm{s}=0.0036 \mathrm{mg} / \mathrm{L}$

Mean value, $\mathrm{x}_{\text {mean }}=0.3009 \mathrm{mg} / \mathrm{L}$

Repeatability $=2.8 * \mathrm{~s}=0.0102 \mathrm{mg} / \mathrm{L}$

Relative standard deviation of the repeatability, $\mathrm{RSD}_{\mathrm{r}}=\mathrm{s} /\left(\mathrm{x}_{\text {mean }} * 100\right)=1.21 \%$ 


\section{INTERNATIONAL SYMPOSIUM "THE ENVIRONMENT AND THE INDUSTRY", SIMI 2018, PROCEEDINGS BOOK}

\begin{tabular}{|c|c|c|c|c|c|}
\hline \multicolumn{6}{|c|}{ Rh, $343.487 \mathrm{~nm}$} \\
\hline \multirow{2}{*}{$\begin{array}{l}\text { Measured values } \\
\text { (mg/L) }\end{array}$} & 0.301 & 0.303 & 0.305 & 0.298 & 0.299 \\
\hline & 0.301 & 0.301 & 0.305 & 0.305 & 0.309 \\
\hline $\begin{array}{l}\text { Standard deviation of } \\
\text { Mean value, } \mathrm{x}_{\mathrm{mean}}=0 \\
\text { Repeatability }=2.8^{*} \mathrm{~s} \\
\text { Relative standard dev }\end{array}$ & $\begin{array}{l}\text { ults, s } \\
\mathrm{lg} / \mathrm{L} \\
5 \mathrm{mg} / \mathrm{L} \\
\text { f the } r\end{array}$ & $1 \mathrm{mg} / \mathrm{L}$ & & $.12 \%$ & \\
\hline
\end{tabular}

Test for intermediate precision (Table 6) have been performed by two analysts (four determination in two different days for each analyst) using the same method and the same equipment.

Table 6. Experiments for intermediate precision

\begin{tabular}{|c|c|c|c|c|c|c|c|c|}
\hline \multicolumn{9}{|c|}{ Rh, 233.477 nm } \\
\hline \multirow{2}{*}{$\begin{array}{l}\text { Measured values } \\
\text { (mg/L) }\end{array}$} & 0.288 & 0.272 & 0.294 & 0.279 & 0.316 & 0.301 & 0.311 & 0.291 \\
\hline & 0.276 & 0.294 & 0.321 & 0.307 & 0.312 & 0.319 & 0.297 & 0.306 \\
\hline $\begin{array}{l}\text { Standard deviation o } \\
\text { Mean value, } \mathrm{x}_{\text {mean }}=0 \\
\text { Repeatability }=2.8^{*} \mathrm{~s} \\
\text { Relative standard de }\end{array}$ & $\begin{array}{l}\text { results, } \\
\mathrm{mg} / \mathrm{L} \\
17 \mathrm{mg} / \\
n \text { of the }\end{array}$ & repeata & ility, RS & $\mathrm{r}=\mathrm{s} /(\mathrm{x}$ & $* 100)$ & $2.02 \%$ & & \\
\hline \multicolumn{9}{|c|}{ Rh, 343.487 nm } \\
\hline \multirow{2}{*}{$\begin{array}{l}\text { Measured values } \\
(\mathrm{mg} / \mathrm{L})\end{array}$} & 0.298 & 0.297 & 0.296 & 0.300 & 0.302 & 0.302 & 0.310 & 0.312 \\
\hline & 0.296 & 0.299 & 0.299 & 0.300 & 0.307 & 0.303 & 0.297 & 0.309 \\
\hline $\begin{array}{l}\text { Standard deviation o } \\
\text { Mean value, } \mathrm{x}_{\text {mean }}=0 \\
\text { Repeatability }=2.8^{*} \mathrm{~s} \\
\text { Relative standard de }\end{array}$ & $\begin{array}{l}\text { results, } \\
\mathrm{mg} / \mathrm{L} \\
17 \mathrm{mg} / \\
\text { of the }\end{array}$ & $\begin{array}{l}=0.006 \\
\text { repeata }\end{array}$ & $\mathrm{mg} / \mathrm{L}$ & 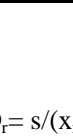 & $k_{1} 10$ & $00 \%$ & & \\
\hline
\end{tabular}

The studies for recovery test was performed using two different drinking water samples and one wastewater sample enriched with $0.4 \mathrm{mg} / \mathrm{L} \mathrm{Rh}$. For each type of matrix, three separate samples were digested with nitric acid ultrapure in order to eliminate organic matter and then analyzed. The obtained results are in Tabel 7.

Table 7. Results for recovery tests

\begin{tabular}{|c|c|c|c|}
\hline \multicolumn{4}{|c|}{ Rh, 233.477 nm } \\
\hline Parameter & $\begin{array}{l}\text { Drinking water } \\
\text { sample } 1\end{array}$ & $\begin{array}{l}\text { Drinking water } \\
\text { sample } 2\end{array}$ & $\begin{array}{c}\text { Wastewater sample } \\
3\end{array}$ \\
\hline $\mathrm{X}_{\mathrm{f}}, \mathrm{mg} / \mathrm{L}$ & 0.0043 & 0.0053 & 0.0223 \\
\hline$\eta, \%$ & 10.83 & 13.33 & 55.83 \\
\hline $\mathrm{S}_{\mathrm{xf}, \mathrm{mg} / \mathrm{L}}$ & 0.0006 & 0.0015 & 0.0023 \\
\hline $\mathrm{S}_{\mathrm{n}}, \%$ & 1.44 & 3.82 & 5.77 \\
\hline \multicolumn{4}{|c|}{ Rh, $343.487 \mathrm{~nm}$} \\
\hline Parameter & $\begin{array}{l}\text { Drinking water } \\
\text { sample } 1\end{array}$ & $\begin{array}{l}\text { Drinking water } \\
\text { sample } 2\end{array}$ & $\begin{array}{c}\text { Wastewater sample } \\
3\end{array}$ \\
\hline $\mathrm{X}_{\mathrm{f}}, \mathrm{mg} / \mathrm{L}$ & 0.0417 & 0.042 & 0.0427 \\
\hline$\eta, \%$ & 104.2 & 105 & 106.67 \\
\hline $\mathrm{S}_{\mathrm{xf}, \mathrm{mg} / \mathrm{L}}$ & 0.0012 & 0.001 & 0.0006 \\
\hline $\mathrm{S}_{\eta}, \%$ & 2.89 & 2.50 & 1.44 \\
\hline
\end{tabular}




\section{INTERNATIONAL SYMPOSIUM "THE ENVIRONMENT AND THE INDUSTRY", SIMI 2018, PROCEEDINGS BOOK}

For 10 to $100 \mu \mathrm{g} / \mathrm{L}$ level of concentration, the recovery percentage must be situated in the $60-115 \%$ range (Tanase 2007 ).

The recovery test indicate that at $233.477 \mathrm{~nm}$ wavelength the recovery percentage is very low, even if the other performance parameters are very good. It is found that only $343.487 \mathrm{~nm}$ is suitable for determination of rhodium from drinking and wastewater samples, recovery percentage higher tahn 104\%.

\section{Conclusions}

The method for rhodium determination at $343.487 \mathrm{~nm}$ using inductively coupled plasma optical emission spectrometry is precise, sensitive and fast, with a good recovery performance and can be used for drinking and wastewater samples.

\section{Acknowledgements}

The authors acknowledge the financial support offered in 2018 by the Romanian Nucleu Programme through Project PN 18050101.

\section{References}

Dai, X, Koeberl, C \& Froschl, H 2001, 'Determination of platinum group elements in impact breccias using neutron activation analysis and ultrasonic nebulization inductively coupled plasma mass spectrometry after anion exchange preconcetration', Analytica Chimica Acta, vol. 436, pp.79-85.

Dinu, LR, Badescu,V, Dediu, V, Cristea, I, Patroescu, V \& Oncu, V 2017, 'Mine water treatment tests results for a continuous flow reaction system' $20^{\text {th }}$ International Symposium “The Environment and the Industry”,SIMI 2017, National Research and Development Institute for Industrial Ecology ECOIND, Bucharest, pp. 61-68.

Djingova, R, Heidenreich, H, Kovacheva, P \& Markert, B 2003, 'On the determination of platinum groupelements in environmental materials by inductively coupled plasma mass spectrometry and microwave digestion', Analytica Chimica Acta, vol.489, pp. 245-251 .

Georgieva, M, Pihlar, B \& Fresenius J 1997, 'Determination of palladium by adsorptive stripping voltammetry', Fresenius Journal of Analycal Chemistry, vol. 357, pp. 874-880.

Gomez, MB, Gomez, MM \& Palacios, MA 2000, 'Control of Interferences in the Determination of Pt, Pd and Rh in Airborne Particulate Matter by Inductively Coupled Plasma Mass Spectrometry', Analytica Chimica Acta, vol. 404, pp. 285-294.

Hibbert, DB 2007, Quality Assurance for the Analytical Chemistry Laboratory, University Press, Oxford, UK.

Kim, L, Muresan, AM, Cuciureanu, A, Guta, D, Arama, M, Cristea, NI, Dediu,V, 2017, Experimental models of characterization and analysis of industrial waste' $20^{\text {th }}$ International Symposium "The Environment and the Industry", SIMI 2017, National Research and Development Institute for Industrial Ecology ECOIND, Bucharest, pp. 142-150.

Kovacheva, P \& Djingova, R 2002, 'Ion-exchange method for separation and concentration of platinum and palladium for analysis of environmental 


\section{INTERNATIONAL SYMPOSIUM "THE ENVIRONMENT AND THE INDUSTRY", SIMI 2018, PROCEEDINGS BOOK}

samples by inductively coupled plasma atomic emission spectrometry', Analytica Chimica Acta, vol. 464, pp.7-13.

Merget, R \& Rosner, G 2001, 'Evaluation of the health risk of platinum group metals emitted from automotive catalytic converters', Science of the Total Environment, vol. 270, pp.165-173.

Muzikar, M, Fontas, C, Hidalgo, M, Havel, J \& Salvado, V 2006, 'A preconcentration system using polyamine Metalfix-Chelamine resin for the on-line determination of palladium(II) and platinum(IV) by inductively coupled plasma optical emission spectrometry', Talanta, vol.70, pp.10811086.

Niemela, M, Peramaki, P, Piispanen, J \& Poikolainen, J, 2004, 'Determination of platinum and rhodium in dust and plant samples using microwave-assisted sample digestion and ICP-MS', Analytica Chimica Acta, vol.521, pp.137142.

Panahi, HA, Kalal, HS, Nezhati, MN, Menderjani, MT, Kelahrodi, SR \& Mahmoudi, F 2009, 'Amberlite XAD-4 functionalized with mphenylendiamine: Synthesis, characterization and applications as extractant for preconcentration and determination of rhodium (III) in water samples by Inductive Couple Plasma Atomic Emission Spectroscopy (ICP-AES)' Microchemical Journal, vol. 93, pp. 49-54.

Parker, AM \& Thoennessen, M 2012 'Discovery of rubidium, strontium, molybdenum, and rhodium isotopes', Atomic Data and Nuclear Data Tables, vol. 98, pp.812-831.

Pawlak, J, Chruscinska, EL \& Chrustowicz, J 2014 'Fate of platinum metals in the environment', Journal of Trace elements in Medicine and Biology, vol. 2, pp. 247-254.

Petrucci, F, Bocca, B, Alimonti, A \& Caroli, S 2000, 'Determination of Pd, Pt and $\mathrm{Rh}$ in airborne particulate and road dust by high-resolution ICP-MS: a preliminary investigation of the emission from automotive catalysts in the urban area of Rome', Journal of Analycal Atomic Spectrometry, vol.15, pp.525-528.

Ravindra, K, Benes, I \& van Grieken, R 2004, 'Platinum group elements in the environment and their health risk' Science of the Total Environment, vol.318, pp.1-43.

Resano, M, Garcia-Ruiz, E, Belarra, MA, Vanhaecke, F \& McIntosh, KS 2007, 'Solid sampling in the determination of precious metals at ultratrace levels', Trends in Analytical Chemistry, vol.26, pp.385-395.

Su, X, Wang, M, Zhang, Y, Zhang, J, Zhang, H \& Jin, Q 2001 'Graphite furnace atomic absorbtion spectrometric determination of some nouble metals using flow injection on-line clean-up', Journal of Analitical Atomic Spectrometry, vol.16, pp.1341-1343.

Tanase, I Gh, Radu, GL, Pana, A \& Buleandra, M 2007, Analytical method validation, Printech Press, Bucharest, pp. 31-35.

Yajun, W \& Xiaozheng, L 2012 'Health risk of platinum group elements from automobile catalysts', Procedia Engineering, vol. 45, pp. 1004-1009.

Zimmermann, S, Menzel, CM, Stuben, D, Taraschewski, H \& Sures, B 2003, 'Lipid solubility of platinum group metals $\mathrm{Pt}, \mathrm{Pd}$ and $\mathrm{Rh}$ in dependece on the presence of complexing agents', Environmental Pollution, vol.124, pp.1-5. 